\title{
RANKING OF UNIVERSITIES IN THE UNITED ARAB EMIRATES: EXPLORING A WEB-BASED TECHNIQUE
}

\author{
K. K. Govender \\ Research Fellow \\ University of KwaZulu-Natal \\ http://orcid.org/0000-0002-3079-5989
}

\section{E. Nel}

Alumni

Da Vinci Institute for Technology Management

Johannesburg, South Africa

http://orcid.org/0000-0002-0029-8308

\section{ABSTRACT}

This study investigated university rankings in the UAE within the context of the challenges facing higher education globally in the $21^{\text {st }}$ century, by using the Webometric ranking methodology. Data was collected and analysed on the top 20 UAE universities. It was apparent that the UAE universities do not perform as well as expected in the Webometrics ranking, when compared with peer countries. The ratings are slightly below that which is expected, especially when one considers measures such as research publications. Strategies to improve performance using the Webometrics indicators could have a positive impact on the UAE universities. Improvements in communicating research and their web presence is likely to move the UAE universities up the Webometrics rankings, and their academic reputation in the country.

Keywords: rankings, higher education, UAE, web rankings, international

\section{INTRODUCTION}

In a complex educational market, higher education institutions (HEIs) are increasingly confronted by challenges such as global competitiveness, mobility, impact, reputation and relevance (McCowan 2016). Higher education institutions need to not only provide knowledge and skills required in knowledge-based economies, but also to conduct relevant research and create knowledge that will support the growth of these economies (Jongbloed, Enders, and Salerno 2008). Universities across the globe are becoming more aware of their position in their regions and the role they have to play in stimulating economic growth and socio-economic development (Alexander 2000). Through state spending, as well as the contribution of students and parents towards university fees, the public has economic and social expectations of the contribution that HEIs make to economic the development and sustainable welfare, growth and 
development of countries (Jongbloed et al. 2008, 304). Stack (2016) argues that the increasing attention being paid to higher education by the media has further placed the outputs and contributions of HEIs under the spotlight. Generally, HEIs have come under public scrutiny from a diverse set of constituents, which include governments, students and their families, donors and funders, and lecturers and researchers.

Since 2003, many ranking systems have been established, and despite active debate over the validity of ranking indicators, the ranking systems have grown in popularity and are seen as a visible measure of global competitiveness and standing (Millot 2015). Rankings have become indicative of a university's ability to compete for top local and international students, staff and researchers, as well as funding and business opportunities (Aguillo et al. 2010; DelgadoMarquez, Hurtado-Torres, and Bondar 2011). Hazelkorn $(2015,140)$ points out that "the perception of quality", which includes the reputation of an institution, is critical when it comes to international students deciding at which university to study. The process also becomes a reinforcing loop whereby higher rankings and higher number of applications received annually, will improve future rankings (Stack 2016). Furthermore, universities across the world benefit from improved rankings, not only in terms of attracting quality students, staff and funding, but also by raising the level of knowledge transfer and innovation (Aguillo et al. 2010; DelgadoMarquez et al. 2011).

In an attempt to secure their share of the international market, universities in the Middle East have taken considerable action to attract more international students (Wilkins, Balakrishna, and Huismans 2012). The United Arab Emirates (UAE) has had a drive over the past decade and a half, to establish many private higher education institutions and fully-fledged international branch campuses, alongside its national universities. The country has been working actively to attract international students and staff to these institutions (Ahmad and Hussain 2015). "Global competitiveness" is also part of the stated vision of the UAE's Ministry of Higher Education and Scientific Research (MOHESR 2014). Ahmad and Hussain (2015) reported that the reputation of UAE institutions, which includes international rankings, is one of the top three influences after the learning environment and cost, in attracting international students to study in the country.

The UAE has highlighted competitiveness, innovation and education as some of its top priorities (UAE Government 2010), and improved rankings at the institutional level will likely to benefit said institutions, as well as the country as a whole. An investigation into the UAE institutions' performance could be beneficial at institutional and national level, in an age where public accountability of higher education and global competition are important to UAE universities, given the government's commitment to deliver tertiary education on a par with 
"recognised institutions of higher education" (Commission of Academic Accreditation 2010, 7).

Although there are several international ranking models, this study seeks to determine if UAE institutions score lower in the Webometrics ranking than the expectations raised by the country's economic performance. The Webometrics ranking, with its strong focus on digital media and overall international impact (Cybermetrics Lab 2017), seems to be in line with international higher education trends, and also with the mission of the UAE and its higher education ministry (MOHESR 2014; UAE Government 2010). A poor relationship between the actual and expected performance may undermine the country's competitiveness in the global higher education market (Hazelkorn 2015).

It is against the above background, this study aims to investigate the methodology employed by Webometrics to determine the rankings of UAE universities and analyse the performance of the universities in terms of their ranking.

\section{LITERATURE REVIEW}

\section{The higher education landscape}

During the past century, higher education has expanded rapidly (Schofer and Meyer 2005) and in 1900, approximately half a million students were enrolled in higher education across the world. By the year 2000, this number had grown to about 100-million people (Schofer and Meyer 2005). Interest from various stakeholders in this (education) industry is likely to grow as enrolment increases "in an era when having a higher education degree is increasingly necessary to assure a smooth transition into the labour market" (OECD 2012, 15).

As producers of human capital and innovation, universities play an important part in the economic growth of any society (Barber, Donnelley, and Rizvi 2013; Valero and Van Reenen 2016). "Marketisation" of higher education has become a reality with students "shopping" for the best higher education offerings across the globe (Barber et al. 2013, 10) and science and technology are becoming more and more important in the global economy. The resulting demand for research and innovation from higher education institutions is placing a larger emphasis on research, as opposed to the teaching and production of undergraduate degrees. The US National Science Foundation (2016) reported that funding of higher education research in the USA, for example, increased from $\$ 250$ million to $\$ 65$ billion in the past 10 years. With the increase in funding, there is an associated greater accountability to funders and government in particular. The fast pace of technological advancement and accompanying easy access to information are starting to drive research from behind the "high premium pay walls of academic 
journals into the open," where scholars and the public can benefit from research that governments and grants have paid for (Anderson, Boyles, and Rainie 2012, 5). The Open Access Initiative, established in 2001, advocates free access to anyone with access to the internet in order to advance scientific research (Budapest Open Access Initiative n.d.)

In the face of the growth in the number of higher education and research providers, as well as the importance attached to them in national and international economies, competition increases among institutions, thus the need for a ranking system to be able to compare them. Hazelkorn $(2015,4)$ argues that the "rankings consciousness" has gained ground in response to globalisation and the pursuit of new knowledge to stimulate economic growth. The ranking awareness is now also part of the drive for increased public accountability and transparency of higher education institutions.

When building the reputation of higher education institutions, there is great emphasis on shifting teaching and research from its "ivory-towered intellectual isolation," back to closer and more continuous contact with the economy, the state, and the community as vital co-producers and consumers of useful knowledge (Sum and Jessop 2013, 34). Faculties are now expected to develop extensive links with users in media, industry, business, the professions, government and local communities (Baron 2010; Sum and Jessop 2013).

Reputations of universities are important, but measuring the true worth of the institution is complicated (Hazelkorn 2015). If one wants to compare universities, given how their reputations rely on the different stakeholder groups, geographical areas, knowledge fields and perceptions that come into play, one would have to reduce these to a single or a few measurable dimensions (Perez-Diaz and Rodriquez 2015). The ranking tables are an attempt to measure quality and performance and to allow universities to be compared with one another using consistent criteria (Hazelkorn 2015).

Using a variety of indicators, ranging from journal publications, international faculty, size, student composition to research collaboration, repositories, and web presence, the rankings create hierarchies by establishing a "single norm for excellence", which are turned into mechanisms or tools for differentiation (Hazelkorn 2015, 13). The top-performing universities are given the lowest number; for example, first or second place, while poorer scoring universities have higher scores (Hazelkorn 2015).

\section{University rankings}

The first global ranking, the Shanghai Jiao Tong Academic Ranking of World Universities (ARWU), used reputational factors and bibliometric indicators, as well as citations drawn from Thomson Reuter's Web of Science and Elsevier's Scopus data (ARWU 2016). The ARWU 
project was followed by Webometrics and the Times QS World University Rankings (THEQS) in 2004, and the Leiden Rankings in 2008. In 2009, the THE-QS rankings split into the QS World University Rankings (QS) and THE World University Rankings (Shin and Toutkoushian 2011). At least another 150 national and global ranking systems have been launched in the past two decades (Hazelkorn 2015). At the time of writing this article, the general consensus in the literature is that Shanghai AWRU, THE, QS and Webometrics are considered the most authoritative ranking systems (Millot 2015; Hazelkorn 2015).

The Shanghai, QS and THE share some common features and have very similar results (Aguillo et al. 2010) and they are also the most widely known of the ranking tables (Millot 2015). Despite a continuing debate about the validity of the choice of indicators and/or their weightings, rankings have acquired legitimacy because the methodology appears statistically rigorous and the various producers willingly engage with critics and occasionally make modifications (Hazelkorn 2015). Usage of the rankings among students, parents, governments, other stakeholders and universities themselves, has also become so established that commentators agree that rankings are here to stay ( $\mathrm{Lu} 2014)$.

While very different in methodology, Webometrics yields striking results which are somewhat different to that produced by other ratings; not only when it comes to overall ranking, but also related to country spread. Webometrics also has the largest number of universities in its analysis (Millot 2015) and the main sources of information from which the rankings are compiled include independent third-party sources, such as government databases, HEI published data and survey data (Hazelkorn 2015).

This study will focus on the Webometrics ranking method since it is considered to have more current and future relevance than the other three systems due to:

- The breadth of institutions covered by this ranking system, thus eliminating the focus on wealthy, elite or traditional Western universities (Millot 2015).

- Its focus on the digital environment that is the main communication platform of this century (Anderson et al. 2012).

- The fact that it takes into account the entire digital footprint of an institution and not just published research (Delgado-Marquez et al. 2011).

\section{Webometrics}

Webometrics is one of the leading global university ranking systems (Hazelkorn 2015; Millot 2015) and there is a strong correlation between its results and those of the other major ranking 
tables (Aguillo 2010). Like the other major ranking tables, Webometrics also has a significant focus on research output, but there are also marked differences in its approach to the ranking methodology. Webometrics differs from the other major ranking systems in that it uses an institution's entire presence and activity on the World Wide Web, as a proxy for its reputation and activity. The word "webometrics" refers to "the quantitative study of web-related phenomena" (Thelwall, Vaughan, and Bjorneborn 2005, 81), since webometrics analyses the nature, structures, and content properties of websites and web pages, as well as the link structures that are important for understanding the web and its connections (Lorentzen 2014). The web presence of an institution reflects not only its global performance, but also the performance of its departments and services, the impact of its outputs, and its international prestige (Altbach 2011; Aguillo and Labajos 2010).

Even though researchers believe that Webometrics accurately portrays the perceived quality of education and academic prestige, other non-academic variables are also considered that add further value and validity to this ranking system (Delgado-Marquez et al. 2011). Aguillo, Ortego and Fernandez (2008) insist that teaching materials, raw data, drafts, slides, software, and bibliographic or link lists are just as relevant to a university's performance as publications in journals. The structure, composition and other administrative information of the institution are also important, and when all of this is made publicly available on the web, "it speaks of the high academic level of the university" (Aguillo et al. 2008, 234).

Because Webometrics includes the most comprehensive list of international universities available at present, it allows universities and colleges worldwide to compare themselves (Rauhvargers 2013). Furthermore, Webometrics includes all universities that have an internet domain that can be found by a search engine, all universities from all over the world and from all economic and political spheres and developing countries included. It is almost the only source of information about universities which are outside of the top 500 positions in the world (Rauhvargers 2013).

Although Webometrics values the research aspect of universities, it also focuses on other aspects such as teaching and this is possible because the transfer of knowledge can be picked up via link analysis (Aguillo and Labajos 2010). This puts Webometrics within reach of all universities, not just the wealthy and the elite; another element that distinguishes it from the other major ranking systems that tend to be dominated by "research-strong universities and universities from wealthy countries" (Marginson 2012, 545). The Webometrics website had about four million visitors by 2010, and averaged about 24500 visitors per month in 2018 . This a good indication of how valuable students consider this ranking table (Aguillo 2010). Table 1 summarises the main indicators that comprise the major ranking systems. 
Table 1: The major ranking indicators and weightings

\begin{tabular}{|c|c|c|c|}
\hline Times Higher Education & QS Top Universities & ARWU Shanghai & Webometrics \\
\hline $\begin{array}{l}\text { Teaching - } 30 \% \\
\text { - } \quad \text { Reputation survey } 15 \% \\
\text { - } \quad \text { Staff to student ratio } 4.5 \% \\
\text { - } \quad \text { Doctorate to bachelor's } \\
\text { ration } 2.25 \% \\
\text { - } \quad \text { Doctorates to academic } \\
\text { staff ratio } 6 \% \\
\text { - } \quad \text { Institutional income } 2.25 \% \\
\text { Research - } 30 \% \\
\text { - } \quad \text { Reputation survey } 18 \% \\
\text { - } \quad \text { Research income } 6 \% \\
\text { - } \quad \text { Research productivity } 6 \% \\
\text { Citations } 30 \% \\
\text { International outlook } 7.5 \% \\
\text { - International to domestic } \\
\text { student ratio } 2.5 \% \\
\text { - International to domestic } \\
\text { staff ratio } 2.5 \% \\
\text { - International collaboration } \\
2.5 \%\end{array}$ & $\begin{array}{l}\text { - Academic reputation } \\
40 \% \\
\text { - } \text { Employer reputation } \\
10 \% \\
\text { - } \text { Student to faculty } \\
\text { ratio } 20 \% \\
\text { - } \text { Citations per faculty } \\
20 \% \\
\text { - } \text { International faculty } \\
\text { ratio } 5 \% \\
\text { - International student } \\
\text { ratio } 5 \%\end{array}$ & 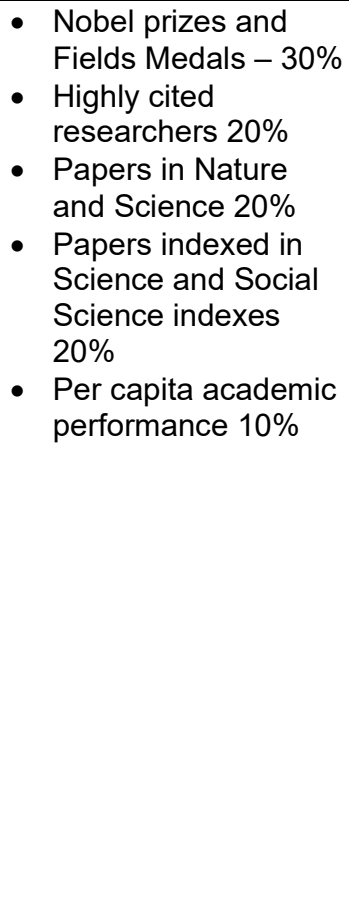 & $\begin{array}{l}\text { - Presence on the web } \\
10 \% \\
\text { - Visibility/lmpact } \\
\text { (inbound links) } 50 \% \\
\text { - Openness (Google } \\
\text { Scholar) } 10 \% \\
\text { - Excellence (cited } \\
\text { papers per } \\
\text { discipline) } 30 \%\end{array}$ \\
\hline
\end{tabular}

It is evident from Table 1 that whereas the THE, QS and ARWU rankings seem to have mostly an inward institutional focus, Webometrics takes cognisance of the impact that institutions have in the world at large, as represented by its presence on the World Wide Web. Webometrics claims to represent not only publications and citations, but also other activities that institutions are engaged with that can be read into their presence on the web (Cybermetrics Lab 2017).

Webometrics seems particularly relevant as the UAE has a reputation as a forward-looking country that embraces technology as a cornerstone of economic development (UAE Government 2010). If an assumption is made that the Webometrics ranking is important to measure the country's competitiveness, a study into the country's universities' Webometrics scores could highlight opportunities and threats in this market (Hazelkorn 2015).

Since some researchers (Lu 2014; Ross 2017) allude to a correlation between a country's per capita GDP and the performance of its universities in the global rankings, the UAE institutions' scores in the Webometrics rankings should then show a positive correlation with the country's GDP. Table 2 reflects the Webometrics rankings of the top 20 UAE universities between July 2012-January 2017.

Table 2 shows that the highest achievement a UAE university has had on the Webometrics ranking over the period, is position 997 (the United Arab Emirates University). 
Table 2: Webometrics ranking of UAE Universities - July 2012 to January 2017

\begin{tabular}{|c|c|c|c|c|c|c|c|c|c|c|}
\hline Institution & Jan-17 & Jul-16 & Jan-16 & Jul-15 & Jan-15 & Jul-14 & Jan-14 & Jul-13 & Jan-13 & Jul-12 \\
\hline United Arab Emirates University & 1129 & 1161 & 1040 & 997 & 1061 & 1033 & 1123 & 1217 & 1167 & 1330 \\
\hline Masdar Institute & 1772 & 1828 & 2297 & 2371 & 3166 & 3184 & 4737 & 4327 & 5717 & 7501 \\
\hline American University of Sharjah & 1804 & 1752 & 2018 & 2055 & 2170 & 2077 & 2869 & 2833 & 2447 & 2643 \\
\hline Khalifa University & 2462 & 2351 & 3354 & 3572 & 5600 & 5863 & 9576 & 9167 & 7053 & 9338 \\
\hline University of Sharjah & 2477 & 2375 & 2644 & 2818 & 4076 & 3821 & 4062 & 3046 & 3266 & 2235 \\
\hline Zayed University & 2583 & 2456 & 2858 & 3090 & 3471 & 3557 & 3319 & 3301 & 3125 & 3740 \\
\hline Petroleum Institute Abu Dhabi & 2807 & 2659 & 3130 & 3390 & 5216 & 4997 & 6084 & 4391 & 5525 & 5469 \\
\hline Higher Colleges of Technology & 3128 & 2842 & 3524 & 3702 & 3294 & 3076 & 3251 & 3273 & 2614 & 2312 \\
\hline Abu Dhabi University & 3628 & 3399 & 5246 & 5526 & 7512 & 6511 & 6850 & 7063 & 6542 & 6052 \\
\hline University of Wollongong in Dubai & 3643 & 4704 & 4387 & 4751 & 7882 & 7533 & 7741 & 5670 & 6335 & 6975 \\
\hline $\begin{array}{l}\text { Ajman University of Science \& } \\
\text { Technology }\end{array}$ & 3831 & 4618 & 4009 & 4423 & 7034 & 6710 & 8639 & 8158 & 7452 & 6864 \\
\hline British University in Dubai & 4270 & 3939 & 4695 & 4903 & 5167 & 5385 & 7684 & 8715 & 5444 & 5005 \\
\hline $\begin{array}{l}\text { American University of Ras al } \\
\text { Khaimah AURAK }\end{array}$ & 4426 & 6818 & 15574 & 16798 & 18611 & 17535 & 16522 & 20247 & 15528 & \\
\hline American University in Dubai & 4461 & 5139 & 6552 & 5493 & 5829 & 4021 & 7434 & 6090 & 6311 & 5719 \\
\hline Al Falah University & 4692 & 5214 & 6698 & & & & & & & \\
\hline Gulf Medical University & 5024 & 8043 & 7411 & 7685 & 8512 & 10513 & 11199 & 8538 & 11702 & 11167 \\
\hline $\begin{array}{l}\text { Al Ain University of Science \& } \\
\text { Technology }\end{array}$ & 5295 & 4486 & 7106 & 5759 & 11912 & 14616 & 15438 & 16855 & 15187 & 16983 \\
\hline University of Dubai & 5364 & 4701 & 9945 & 9909 & 13098 & 12546 & 11460 & 12245 & 10194 & 10822 \\
\hline Canadian University of Dubai & 6350 & 4706 & 5484 & 5490 & 5414 & 5442 & 5155 & 5080 & 5203 & 5230 \\
\hline Alhosn University & 6636 & 6026 & 8650 & 9634 & 11072 & 9777 & 10662 & 10659 & 9093 & 10566 \\
\hline
\end{tabular}

Source: Cybermetrics Lab 2017. 
The UAE was also listed at position 54 in the world when the top 5000 universities in the world were taken into account (Cybermetrics Lab 2017). Thirty countries with weaker GDP figures (World Bank 2016) were ranked higher on the Webometrics country scores. These included countries such as Brazil (ranked $10^{\text {th }}$ ), Algeria (ranked $18^{\text {th }}$ ), Bangladesh (ranked $21^{\text {st }}$ ), Colombia (ranked $24^{\text {th }}$ ) and Nigeria (ranked $38^{\text {th }}$ ).

The Scimago country data used by Webometrics compared with GDP rankings, also confirms that the UAE universities are performing below their economic peers, as can be seen from Table 3 (World Bank 2016).

Table 3: Countries with Similar GDP to the UAE

\begin{tabular}{|l|c|c|c|c|c|c|}
\hline \multicolumn{1}{|c|}{ Country } & GDP Rank & Documents & Citable documents & Citations & $\begin{array}{c}\text { Citations per } \\
\text { Document }\end{array}$ & H Index \\
\hline USA & 1 & 9360233 & 8456050 & 202750565 & 21,66 & 1783 \\
\hline Austria & 29 & 295668 & 273467 & 5052810 & 17,09 & 487 \\
\hline Venezuela & 30 & 33780 & 32445 & 321006 & 9,5 & 166 \\
\hline UAE & 31 & 31366 & 29259 & 210873 & 6,72 & 130 \\
\hline Egypt & 32 & 137350 & 33147 & 1009954 & 7,35 & 184 \\
\hline South Africa & 33 & 188104 & 172424 & 2125927 & 11,3 & 320 \\
\hline Hong Kong & 34 & 219177 & 206011 & 3494244 & 15,9 & 392 \\
\hline Norway & 35 & 229276 & 209259 & 3951661 & 17,24 & 439 \\
\hline
\end{tabular}

Source: World Bank 2016

The architects of Webometrics consider subdomains favourably as a "measure of the maturity of the whole domain" (Aguillo 2009, 543). The rationale being that a university with a significant web presence, might require different domains to curate information and host large repositories in different servers, or need subdomains for subject experts to manage the specialised information or data types. Within the enterprise architecture, subdomains are generally thought to improve access to information and it makes identification of information in the web architecture easier.

\section{RESEARCH METHODOLOGY}

\section{Research context}

The UAE has a rapidly expanding higher education sector with a mix of private and public institutions and over the past decade, the UAE has become an academic destination for international students (MOHESR 2014). The UAE has also implemented various policies to promote itself as a knowledge and education hub in the region (Ahmad and Hussain 2015), and has set higher education as a key priority in the UAE's Vision 2021 national agenda (Rensimer 
2015).

In 2013, the UAE had 81 higher education institutions, four public and 77 private institutions; of which 10 are licenced branch campuses of international institutions (MOHESR 2014). Approximately 110000 students had been enrolled in higher education institutions by 2011 of which 62 per cent were local nationals and 38 per cent international students (Rensimer 2015).

In 2012, most universities in the UAE did not have a research budget, and only 13 reported a budget of about $\$ 27000$ (CHEDS 2012). Furthermore, the majority of institutions did not possess a system that enabled them to record and validate the publications of their faculty (CHEDS 2012). Because of the lack of information, they could not determine the number of publications per institution or researcher at the time. However, Abu Dhabi as an Emirate, is for instance strengthening its research capacity by partnering with internationally recognised research centres and universities and sponsoring major research initiatives in several sectors (Knight 2013).

Although competitiveness is listed in the mission statement of the MOHESR (MOHESR 2016), there is very little reference to rankings or ratings in publicly available government communications on higher education. Although in its 2012 report, the CHEDS seems to suggest that ranking tables were not greatly valued (CHEDS 2012, 36), it did concede that there would be value in clustering institutions together based on shared characteristics and then perform a comparison.

\section{Research method}

A mixed methods study was conducted to address the aims and objectives of this research. Secondary (published) data were collected through a review of documents and online resources of the UAE universities. Numerical data of the Webometrics rankings, performance on various indicators, the online presence of UAE universities, as well as existing processes and systems at UAE universities were considered.

This research represented a cross-sectional design, where UAE universities were listed in terms of their rankings using Webometrics (Saunders, Lewis, and Thornhill 2016). There was also a longitudinal element to the study in the form of historical ranking of data, particularly from the past 10 ranking cycles (from July 2012 to January 2017) (Saunders et al. 2016). Longitudinal and snapshot data from Webometrics and Scimago, namely, data on the institutions' presence on the internet sourced through Google site tools, as well as MajesticSEO were used. 


\section{Sample and sampling}

The population comprised all the higher education institutions in the UAE, however, the sampling frame included only those institutions with a presence on the World Wide Web, and thus comprised 51 institutions (Cybermetrics Lab 2017). A non-probability sampling strategy was used, where the institutions that performed in the top 20 in the UAE during period of study, were the focus on. For comparison with peer countries at an economic level, the top five universities in each country were selected for ease of comparison.

\section{Data collection and analysis}

The data was obtained through Google observations of the online presence of the university related to research visibility and included:

- Corporate website searches using no more than ten clicks from the landing page

- Google searches in the news category

- Social media accounts on Twitter, Facebook and Instagram

- Trust flows and back-linked data.

The data analysed represents the number of pages indexed by Google in a university's domain and the tool used for this was the "Indexed Pages" search on WebmasterWorld.com. The data on the corporate website size was collected via a Google site count tool using the command site www.institution.edu. The data was updated on 26 March 2017, and although the indexed pages changed daily and would not be the same as what the Webometrics' team would have gathered on a specific date in January 2017, the indexed pages reflect accurately on the "Presence" rank.

Webometrics uses four main indicators, namely, visibility, presence, openness, and excellence to determine a university's standing in the global rank. Visibility is measured by the number of inbound links received by a domain, while also examining where the domain links originate. This reflects that the impact of published material and in-links comply with the same concept as a bibliographical citation (Delgado-Marquez et al. 2011).

In 2014, Webometrics started to ignore the top 10 referring domains, mainly because the architects found that the top referring domains were often from other parts of the university's web presence; for example, the library, referring to the top domain (Cybermetrics Lab Ranking Web of Universities 2016). Cybermetrics, the originators of Webometrics, found that since the establishment of the rankings, many institutions tried to manipulate the rankings and put up mirror domains; for example, to generate inbound links (Cybermetrics Lab 2017). Since there 
is a continuous effort to improve the validity and quality of the rankings, from the 2016 version, the system now discounts the top 20 referring domains and then starts counting the links as generated by two systems, namely, MajesticSEO and Ahrefs. ${ }^{1}$

The presence indicator gives recognition to the global demand for academic information and the need for a strong and detailed web-presence, providing all the information that a stakeholder needs to reflection on what happens in the physical campus space (DelgadoMarquez et al. 2011).

The openness indicator recognises the global effort to set up institutional research repositories and looks at publications over the past five years (Cybermetrics Lab 2017). Data from the top 10 public profiles of each university are collected to allow for size independent comparisons and the first profile is excluded to improve representativeness. For the other nine, the number of citations is added, and institutions are ranked on this (Cybermetrics Lab 2017). Several options are available to deal with bad practices such as duplication of profiles or where papers are not signed by the author (Cybermetrics Lab 2017).

Webometrics bases its excellence indicator on data extracted from Scimago, which is considered to be a global ranking system which examines only publications and citations of about 3000 universities globally, and ranks journals in different fields of study (Rauhvargers 2013). Because of the number limitation by Scimago, the Webometrics excellence indicator takes into account only the ranking of an institution on the Scimago list. Universities that do not make the Scimago list are all assigned the lowest number of that Scimago ranking at the time (Cybermetrics Lab Ranking Web of Universities 2016).

Webometrics relies on the major search engines like Google, and points out that search engines already have sophisticated and tested robots and tools that can be customised with powerful operators for data extraction. Moreover, search engines are already the main intermediaries in web navigation, and the scope of the presence of a domain in their databases reflects its visibility (Aguillo et al. 2008). The specific processes, algorithms and commands used to perform the Webometrics ranking are not disclosed by Cybermetrics (Cybermetrics Lab 2017). The Webometrics ranking methodology, indicators, and weightings are continually adjusted to provide a better classification and stability between editions, and eliminate loopholes and problems (Cybermetrics Lab 2017).

\section{Research Findings}

Figure 1 reflects how the UAE universities performed on each of the indicators, as well as worldwide. A clear trend can be seen where the universities in question underperformed significantly in the areas of Impact/Visibility and Presence, and that the performances in 
Openness and Excellence were more successful compared with other universities in the world. In a strategy to improve Webometrics ranking, UAE institutions should focus on the Presence and Impact/Visibility indicators. It is within the means of these universities to address several shortcomings in these two indicators, and that should see an improvement in the short- to medium-term.

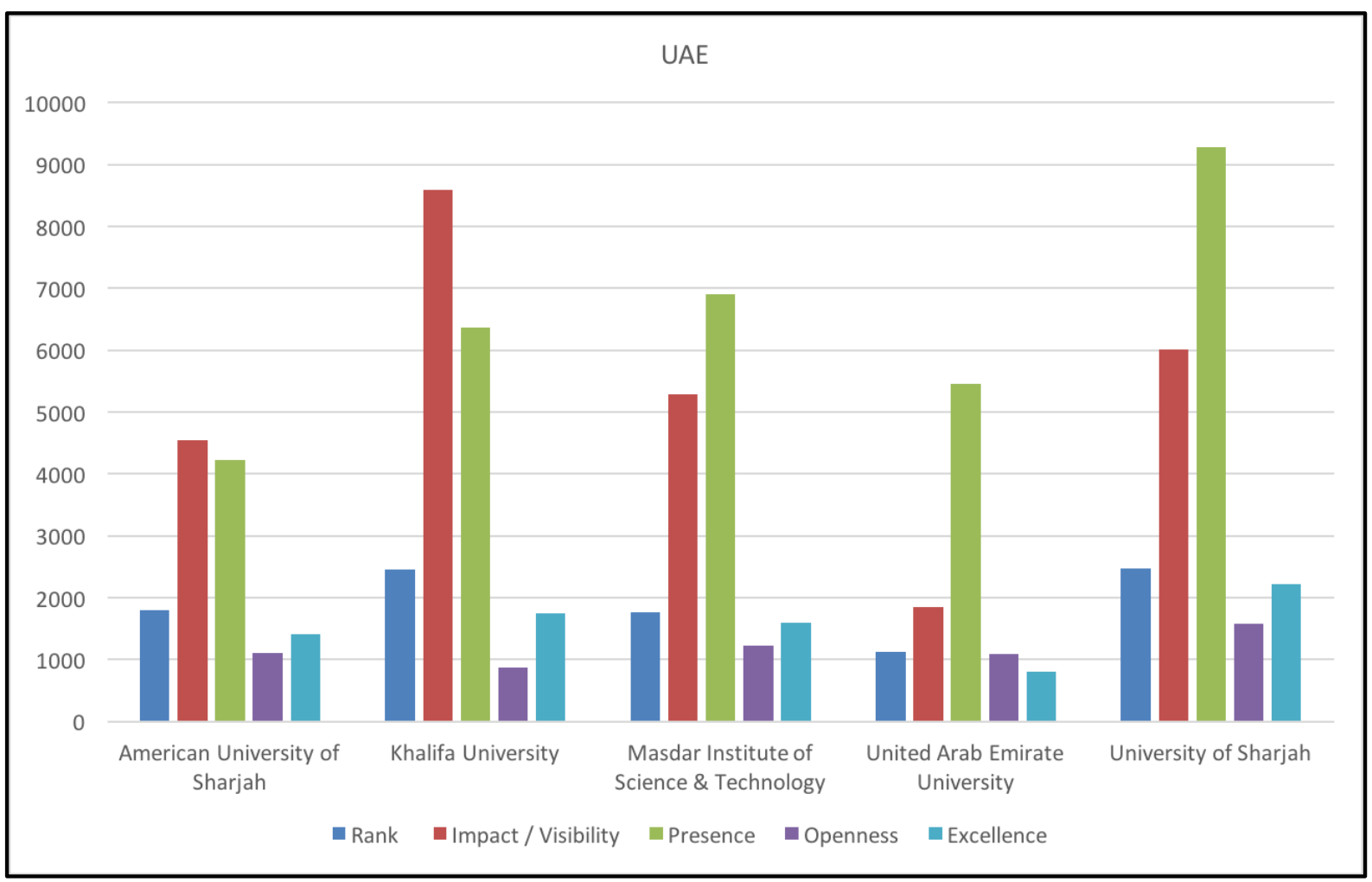

Figure 1: Overall Webometrics performance of top UAE universities

In the case of Openness and Excellence, the UAE institutions seem to be heading in the right direction, with increased focus on research and post-graduate programmes envisaged for the future. Since the UAE universities perform poorly in the Presence and Impact/Visibility indicators relative to the Openness and Excellence indicators, it may be advisable to initially focus on strategies that will see an improvement in their online presence and communication of the impact the institutions are having in the region.

One of the differences between Webometrics and the other three rankings is the fact that the other ranking models have a strong focus on research outputs. From the analysis it is clear that the Openness and Excellence indicators of Webometrics directly relate to scholarly output, making up 40 per cent of the total weighting as reflected in Table 4. 
Table 4: Webometrics indicators relying on citations

\begin{tabular}{|l|l|c|l|c|}
\hline \multicolumn{1}{|c|}{ Indicator } & \multicolumn{1}{|c|}{ Method 2014 } & $\begin{array}{c}\text { Weighting } \\
\mathbf{2 0 1 4}\end{array}$ & \multicolumn{1}{c|}{ Method 2016 } & $\begin{array}{c}\text { Weighting } \\
\mathbf{2 0 1 6}\end{array}$ \\
\hline Openness & $\begin{array}{l}\text { Number of files of the } \\
\text { extension types .pdf, .ps, .doc } \\
\text { and .ppt using Google Scholar }\end{array}$ & $16.67 \%$ & $\begin{array}{l}\text { Data from Google } \\
\text { Scholar Citations on } \\
\text { institutional profiles }\end{array}$ & $10 \%$ \\
\hline Excellence & $\begin{array}{l}\text { Scimago data of the top 10\% } \\
\text { most cited papers by discipline } \\
2008-2012\end{array}$ & $16.67 \%$ & $\begin{array}{l}\text { Scimago data of the top } \\
10 \% \text { most cited papers } \\
\text { by discipline 2010- } \\
2014\end{array}$ & $30 \%$ \\
\hline
\end{tabular}

It is evident from Table 4 that the weighting of the citations, as provided by Scimago, has also increased since the inception of the ranking table. It is important to note that Scimago draws its data from the online databases of Scopus and Elsevier, using a version of the Google PageRank algorithm to do so (SJR 2016). The Scimago algorithm rates journals and assigns weightings to them whereas the Openness indicator uses the Google Scholar digital platform to measure the citations linked to institutional profiles.

The other two indicators, Presence and Visibility, have much to do with the impact and role of universities in their societies; namely, what is being done with the research, whether it is out in the open for everyone to see and whether the research relates to actual interest from other stakeholders such as governments, funders, other academic and research institutions, and the public in general.

One conclusion that can certainly be drawn is that Webometrics may be ahead of the other ranking systems, since not only is the focus largely digital, but it is also takes into cognisance of the changing role of universities in society.

\section{DISCUSSION OF KEY FINDINGS}

Webometrics has a strong citation influence, just as the other major ranking systems do which means that performing well in the Webometrics ranking is not just about the university's website and digital presence. Thus, working on this element of the Webometrics ranking will positively impact all other ranking systems.

The societal and economic impact of the work done at universities is becoming more important, and Webometrics is the only ranking system currently attempting to bring this impact into its measurement metrics. This trend is likely to continue, and therefore paying more attention to the impact of research and how this is communicated will impact positively on Webometrics, as well as likely to have a real impact on the standing of the university in general in the short- to medium-term future.

The future of communication and education lies squarely in the digital domain and online environments for the foreseeable future. Paying attention to a ranking system that acknowledges 
this trend seems prudent, not just for improving performance on this table, but also for keeping abreast of the digital challenges in the world of higher education.

It is also evident that UAE universities are underperforming in the international Webometrics ranking of universities when compared with their peers. Within the context of trends in the international higher education arena, where competitiveness among institutions across the world has become part of the landscape, under-performance in these rankings negatively affects the UAE universities.

Internationally, the trend is for researchers to realise that simply publishing in journals is no longer enough to bolster their own and the reputation of their institution. Funders, students, the public, and many other stakeholders want to see what universities are doing with public money and how they improve the societies in which they function. These stakeholders look for this information mostly online. Webometrics is the one ranking agency that takes this online focus seriously and evaluates universities on their online academic presence. However, the research into the methodology of Webometrics and the practices at UAE universities has highlighted the performance gaps. While UAE universities perform just below average in the Excellence and Openness indicators, they do not do well in the Visibility/Impact or the Presence indicators, when compared with other universities in the same economic bracket. This shows that while faculty members are publishing extensively (considering how few universities have $\mathrm{PhD}$ programmes or a strong research focus), they are severely under-communicating this fact.

The universities in the UAE need to create institutional repositories for their research to be published in an open access environment. Content on websites and other digital platforms should be expanded to include more academic and research content, instead of focusing on institutional events. The academic articles should include cross-referencing links to publications and profiles to boost citations and visibility.

The study has shown that there are strong publication ethics in the top UAE universities, and that at the national and institutional level, there is a drive towards excellence and competitiveness in academic output. The work is being done, but now institutions need to showcase their knowledge creation and the impact they are having at the national, regional and international level. When descending from their proverbial academic ivory towers, and spreading their academic knowledge and outputs in the digital world, UAE universities will not only improve their Webometrics ranking to levels competitive with their peers, but they are also bound to benefit on many levels from an enhanced and sustainable academic reputation.

This study has shown that globalisation has made competitiveness in the higher education sector very important and universities are being judged against their competitors locally and internationally, by students, academics, government agencies, funders, and the public in 
general. The ranking tables are assisting these stakeholders in their comparisons, and performance in the rankings is increasingly impacting universities when decisions about funding, enrolment and public support are being made.

In the current global higher education environment, the impact of digital communications has reverberated, and will continue to do so in classrooms, laboratories, libraries and board rooms. Communicating academic outputs has become as important as communicating course offerings, and with the growth of digital communication platforms, universities must be strategic in positioning their academic and research outputs online. If a university generates research outputs, it needs to be well managed and published in online research repositories and a communications strategy should be in place to create awareness of and links to, this research. Webometrics measures this performance in the international HE arena. Figure 2 illustrates the researchers' interpretation of the Webometrics value chain.

When a university improves its performance in the Webometrics ranking, it is likely to improve in the other global rankings. Improved performance in the rankings will create competitive advantages for the university when it comes to partnerships, funding, recruitment, reputation and many more. Improvement at the institution level allows a positive impact on the elements that drive universities, viz. the research, reputation, repositories, facilities, students, faculty, infrastructure, partnerships and support services. Along with internal policies and procedures to drive these processes, and make them visible, these improvements will propel the university higher up on the Webometrics table and create a positive, reinforcing feedback loop.

\section{CONCLUSION AND RECOMMENDATIONS}

Like all ranking systems and models, the Webometrics ranking is sometimes also criticised because the proxies it uses for a university's performance are considerably less direct than those used by THE, QS and Shanghai (Rauhvargers 2013). However, the correlation with other global rankings, such as QS, THE and Shanghai, is very high, and outliers are easily explained (Aguillo 2010; Delgado-Marquez et al. 2011). Aguillo (2010) explains that while the proxies may be indirect, Webometrics makes use of "big numbers" with the citation and link data, for example, running into tens and hundreds of thousands. "Certainly the web indicators are noisier, but statistically they are better suited for uncovering patterns and discriminating larger number of institutions" (Cybermetrics Lab 2017, n.p.). The Webometrics ranking differs in methodology from the THE, QS and Shanghai ARWU rankings in that whereas the latter three tend to focus on publication and citation counts, student to faculty ratio, the percentage of international students, Nobel and other prizes awarded, and articles published in Science and Nature, Webometrics focuses on web visibility (Aguillo et al. 2010). 


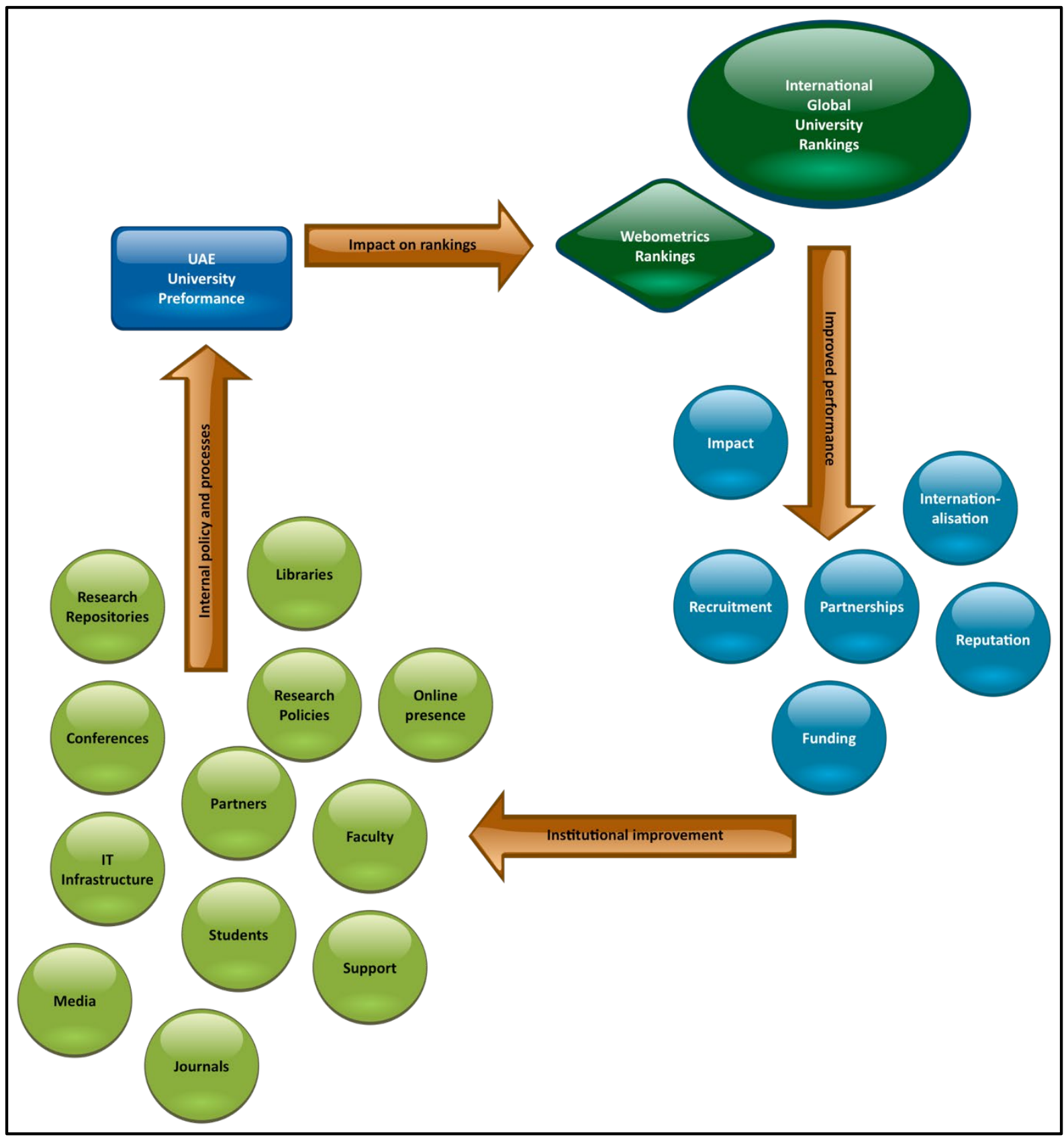

Figure 2: Webometrics performance framework (Source: Developed by the Researcher)

In order to improve their Webometrics ranking and enhance their international reputation, the following are recommended for UAE universities at various decision-making levels.

- Strategic level

\begin{tabular}{|l|l|}
\hline \multicolumn{1}{|c|}{ Action } & Responsible unit \\
\hline $\begin{array}{l}\text { Webometrics to be included as a means to measure international } \\
\text { competitiveness }\end{array}$ & Top management \\
\hline Create a sustainable strategy to improve in the Webometrics ranking. & Top management \\
\hline $\begin{array}{l}\text { Create a strategic plan to communicate the institution's research, the } \\
\text { management and reporting thereof, as well as the communication strategies } \\
\text { surrounding these. }\end{array}$ & Top management \\
\hline
\end{tabular}




\begin{tabular}{|l|l|}
\hline \multicolumn{1}{|c|}{ Action } & Responsible unit \\
\hline $\begin{array}{l}\text { Institute change management to get co-operation and collaboration among } \\
\text { academic staff, post-graduate students, research support, library and } \\
\text { repository staff, the ITC supporting infrastructure and the } \\
\text { marketing/communication division in order to create a value chain for building } \\
\text { research reputation. }\end{array}$ & Top management \\
\hline Create budgets for repositories, communication and research support. & Top management \\
\hline Build on expanding research and post-graduate programmes. & Top management \\
\hline
\end{tabular}

- Operational level

\begin{tabular}{|l|l|}
\hline \multicolumn{1}{|c|}{ Action } & \multicolumn{1}{|c|}{ Responsible unit } \\
\hline $\begin{array}{l}\text { Institute awareness among research staff on the importance of } \\
\text { communicating research and assisting in the curation thereof. }\end{array}$ & $\begin{array}{l}\text { Faculties/Schools } \\
\text { Research Office }\end{array}$ \\
\hline $\begin{array}{l}\text { Implement a domain development policy where the availability and } \\
\text { extent of the university's top domain are managed, and subdomains } \\
\text { are named and expanded in ways that will benefit the institution and } \\
\text { the Webometrics ranking. }\end{array}$ & Information Technology \\
\hline $\begin{array}{l}\text { Encourage the use of links to scholarly profiles and published research } \\
\text { through social media posts and any other platforms to improve } \\
\text { visibility. }\end{array}$ & $\begin{array}{l}\text { Faculties/Schools } \\
\text { Research Office } \\
\text { Marketing/Communication }\end{array}$ \\
\hline Develop and maintain Open Access Research Repositories. & Library \\
\hline Develop and maintain Google Scholar profiles. & Faculty/Schools \\
\hline $\begin{array}{l}\text { Re-evaluate the website platform, content and publication policies to } \\
\text { allow the website to be used not just as a brochure but also as an } \\
\text { organically growing system that supports academic and research } \\
\text { communication. }\end{array}$ & $\begin{array}{l}\text { Information Technology } \\
\text { Marketing/Communication }\end{array}$ \\
\hline $\begin{array}{l}\text { Seek partnerships at all levels with other educational and } \\
\text { governmental institutions in order to create strong links and referring } \\
\text { domains. }\end{array}$ & All levels \\
\hline $\begin{array}{l}\text { Create regular, integrated communication campaigns centred on } \\
\text { research and scholarly outputs. }\end{array}$ & $\begin{array}{l}\text { Marketing/Communication } \\
\text { Faculty }\end{array}$ \\
\hline $\begin{array}{l}\text { Record, maintain and evaluate details of academic publications, } \\
\text { profiles, conference attendance and participation. }\end{array}$ & Research Support \\
\hline $\begin{array}{l}\text { Develop and implement academic communication skills training among } \\
\text { post-graduate students and research staff. }\end{array}$ & $\begin{array}{l}\text { Marketing/Communication } \\
\text { Research Office }\end{array}$ \\
\hline $\begin{array}{l}\text { Institute recognition schemes for research staff that participates in } \\
\text { media campaigns, generate external links and generally promote the } \\
\text { university's academic reputation. }\end{array}$ & Research Office \\
\hline $\begin{array}{l}\text { Periodically monitor and evaluate institutional performance in } \\
\text { Webometrics ranking. }\end{array}$ & Institutional Effectiveness \\
\hline
\end{tabular}

\section{NOTE}

1. Ahrefs is a simple to use SEO.

\section{REFERENCES}

Aguillo, I. 2009. "Measuring the institution's footprint on the web." Library Hi Tech 27(4): 540-556.

Aguillo, I. F. 2010. Web, webometrics and the ranking of universities. http://www.enideurope.org/conference/abstracts/Aguillo\%20(Higher\%20Education).pdf. (Accessed 15 September 2014).

Aguillo, I. F., J. Bar-Ilan, M. Levene, and J. I. Ortega. 2010. "Comparing university rankings." Scientometrics 85(1): 243-256.

Aguillo, I. F. and N. G. Labajos. 2010. "Ranking Web of World Universities.” Journal of International 
Higher Education 3(4): 153-156.

Aguillo, I. S., J. L. Ortega, and M. Fernandez. 2008. "Webometric Ranking of World Universities: Introduction, Methodology, and Future Developments." Higher Education in Europe 33(2|3): 233-244.

Ahmad, S. Z. and M. Hussain. 2015. "An investigation of the factors determining student destination choice for higher education in the United Arab Emirates." Studies in Higher Education October issue.

Alexander, F. K. 2000. "The changing face of accountability." Journal of Higher Education 71(4): 411431.

Altbach, P. 2001. "Higher Education and the WTO: Globalization run amok." International Higher Education 23(Spring issue).

Anderson, J. Q., J. L. Boyles, and L. Rainie. 2012. The future of HIgher Education. http://www.pewinternet.org/2012/07/27/the-future-of-higher-education/. (Accessed 4 November 2016).

ARWU. 2016. ARWU2016. http://www.shanghairanking.com/. (Accessed 14 October 2016).

Barber, M., K. Donnelly, and S. Rizvi. 2013. An avalanche is coming: Higher education and the revolution ahead. USA: Institute for Public Policy Research.

Baron, N. 2010. Escape from the Ivory Tower - A Guide to Making Your Science Matter. Washington: Island Press.

Budapest Open Access Initiative. n.d. Budapest Open Access Initiative. https://www.budapest openaccessinitiative.org/. (Accessed 21 Aug 2019).

CHEDS. 2012. Indicators of the UAE Higher Education Sector: Volume 1. Abu Dhabi: CHEDS.

CHEDS. 2013. Indicators of the UAE Higher Education Sector-International Comparison. Abu Dhabi: CHEDS.

Commission of Academic Accreditation. 2010. CAA Strategic Plan 2008-2014. https:/www.caa.ae/caa/DesktopDefault.aspx?tabindex $=1 \&$ tabid=60. (Accessed 10 November 2016).

Cybermetrics Lab. 2017. Ranking Web of Universities. http://webometrics.info. (Accessed 13 February 2017).

Cybermetrics Lab Ranking Web of Universities. 2016. Countries arranged by Number of Universities in Top Ranks. http://www.webometrics.info/en/node/54. (Accessed 1 November 2016).

Delgado-Marquez, B. L., N. E. Hurtado-Torres, and Y. Bondar. 2011. "Internationalization of Higher Education: Theoretical and Empirical Investigation of Its Influence on University Institution Rankings." International Journal of Educational Technology in Higher Education 8: 265-284.

Hazelkorn, E. 2015. Rankings and the Reshaping of Higher Education - The Battle for World Class Excellence. $2^{\text {nd }}$ Edition. Dublin: Palgrave MacMillan.

Jongbloed, B., J. Enders, and C. Salerno. 2008. "Higher education and its communities: Interconnections, interdependencies and a research agenda." Higher Educataion 56: 303-324.

Knight, J. 2013. "Education hubs: International, regional and local dimensions of scale and scope." Comparative Education 49(3): 374-387.

Lorentzen, D. G. 2014. "Webometrics benefitting from web mining? An investigation of method and applications of two research fields." Scientometrics 99(2): 409-445.

Lu, C. T. K. 2014. "University rankings game and its relation to GDP per capita and GDP growth." International Journal for Innovation Education and Research 2(4).

Majestic. MajesticSEO. https://majestic.com. (Accessed 15 February 2017).

Marginson, S. 2012. "Global University Rankings: The strategic issues." The Journal of Higher Education 84(4): 544-568. 
McCowan, T. 2016. "Universities and the post-2015 development agenda: An analytical framework." Higher Education 72: 505-523.

Millot, B. 2015. "International Rankings: Universities vs higher education systems." International Journal of Educational Development 40: 156-165.

MOHESR. 2014. The UAE Higher Education Factbook 2013/2014. Abu Dhabi: MOHESR.

National Science Foundation. 2016. Higher education R\&D expenditures. https://ncsesdata.nsf.gov/ herd/2015/html/HERD2015_DST_01.html. (4 November 2016).

OECD. 2012. Education at a Glance 2012 - OECD Indicators. Paris: OECD Publishing.

Perez-Diaz, V. and J. C. Rodriquez. 2015. Position Paper: The Reputation of Universitiies. USA: Navara.

Rauhvargers A. 2013. Global University Rankings and Their Impact - Report II. https://eua.eu/downloads/publications/global\%20university\%20rankings\%20and\%20their\%20im pact\%20-\%20report\%20ii.pdf. (Accessed 21 September 2016).

Rensimer, L. 2015. Higher Education in Ras al Khaimah: Polcies, Problem Areas, and Promise. UAE: Ras al Khaimah.

Ross, D. 2017. THE data blog: how university excellence relates to country income. https://www.timeshighereducation.com/blog/data-blog-how-university-excellence-relatescountry-income. (Accessed 6 November 2017).

Saunders, M., P. Lewis, and A. Thornhill. 2016. Research methods for business students. $7^{\text {th }}$ Edition. Essex: Pearson.

Schofer, E. and J. W. Meyer. 2005. The World-Wide Expansion of Higher Education. http://faculty.sites.uci.edu/schofer/files/2011/03/Schofer-Meyer-Higher-Education-ASR.pdf. (Accessed 6 November 2017).

Shin, C. S. and R. K. Toutkoushian. 2011. The Past, Present, and Future of University Rankings. In University Rankings - Theoretical Basis, Methodology and Impacts on Global Higher Education. USA: Springer.

SJR. 2016. Scimago Journal \& Country Rank. http://www.scimagojr.com/. (Accessed 17 October 2016).

Stack, M. 2016. Global University Rankings and the Mediatization of Higher Education. Palgrave MacMillan.

Sum, N. L. and B. Jessop. 2013. "Competitiveness, the Knowledge-Based Economy and Higher Education." Journal of the Knowledge Economy 4(1): 22-44.

Thelwall, M., L. Vaughan, and L. Bjorneborn. 2005. "Webometrics." Annual Review of Information Science and Technology: 81-135.

UAE Government. 2010. UAE Vision. https://www.vision2021.ae/en/our-vision. (Accessed 21 August 2017).

Valero, A. and J. Van Reenen. 2016. The Economic Impact of Universities: Evidence from Across the Globe. London: London School of Economics and Political Science.

Wilkins, S., M. S. Balakrishna and J. Huismans. 2012. "Student choice in higher education: Motivations for choosing to study at an international branch campus." Journal of Studies in International Education 15(5): 413-433.

World Bank. 2016. GDP ranking 2015. http://data.worldbank.org/data-catalog/GDP-ranking-table. (Accessed 1 November 2016) 